\title{
Standarisasi Perjanjian Baku Pada Perbankan Syariah
}

\author{
Moh abdul Latif \\ Fakultas Syariah IAIN Kudus \\ latifabd666@gmail.com
}

\begin{abstract}
The legal relationship applies general terms and conditions set forth in the standard agreement. In connection with the legal relationship between Islamic banks and their customers, they will be questioned, especially those who do not understand the law, what law will be applied in the event of a dispute between Islamic banks and customers regarding the use of an Islamic banking service? Will the existing Islamic law apply to the disputes that arise? Or what will be applied are the terms and conditions set forth in the agreement? This question needs to be raised and the answer is needed to avoid misunderstandings for those who are lawless who intend to connect with Islamic banks, because at this time Indonesia does not yet have Standardization in the form of a Law on standard agreements. therefore it is very necessary to standardize the agreements that apply to the relationship between Islamic banks and their customers by Indonesian banks.

Keywords: Standardization, Standard Agreement, Sharia Principles
\end{abstract}

\begin{abstract}
Abstrak
Hubungan hukum itu berlaku ketentuan-ketentuan dan syarat-syarat umum yang dituangkan dalam perjanjian baku. Sehubungan dengan hubungan hukum antara bank syariah dan nasabahnya akan dipertanyakan, terutama oleh mereka yang kurang memahami hukum, hukum apakah yang akan diberlakukan dalam hal terjadi sengketa antara bank syariah dan nasabah mengenai penggunaan suatu jasa perbankan syariah? Apakah terhadap sengketa yang timbul akan diberlakukan hukum Islam? Ataukah yang akan diberlakukan adalah ketentuanketentuan dan syarat-syarat yang dituangkan di dalam perjanjian? Pertanyaan ini perlu dikemukakan dan jawabanya sangat diperlukan untuk menghindarkan kesalahpahaman bagi mereka yang awam hukum yang bermaksud untuk berhubungan dengan bank syariah, karena pada saat ini Indonesia belum memiliki Standardisasi berupa Undang-undang tentang perjanjian baku, oleh karenanya sangat diperlukan penyeragaman perjanjian-perjanjian baku untuk memberikan kesimbangan antara bank syariah dan para nasabahnya oleh bank Indonesia.
\end{abstract}

Kata Kunci: Standardisasi, Perjanjian Baku, Prinsip Syariah

\section{PENDAHULUAN}

Melalui perjalanan yang sangat panjang dari berbagai peraturan yang sangat minim dan tersebar dalam berbagai bentuk aturan Perundang-undangan, dorongan untuk membuat sebuah Undang-undang khusus tentang perbankan syariah sangat tinggi, baru kemudian Lahirlah Undang-undang Nomor 21 Tahun 2008 tentang Perbankan Syariah. Kelahiran Undang-undang Nomor 21 Tahun 2008 tentang perbankan 
syariah merupakan sebuah momentum atas suatu hal yang sudah lama ditunggu-tunggu oleh berbagai pihak terkait dengan pengembangan industri perbankan syariah. (Agus Triyanta, 2016: 28). Dengan lahirnya Undang-undang Nomor 21 Tahun 2008 tentang Perbankan Syariah, berbagai persoalan yang belum diatur oleh peraturan sebelumnya sudah diproses dalam bentuk pengaturan yang lebih terperinci. banyak juga aspek dari pengaturan yang ada dalam Undang-undang ini yang sebenarnya itu sudah ada dalam peraturan Perundang-undangan sebelumnya, yang kemudian diangkat dalam Undang-undang ini. Tentu saja hal ini ada tujuan penguatan. Namun, masih banyak problematika hubungan hukum antara bank syariah dan para nasabahnya akan dipertanyakan, terutama oleh mereka yang kurang memahami hukum.

Jika diamati detailnya, berbagai aspek yang mendapat penegasan yang menonjol adalah masalah perjanjian baku yang dibuat oleh para pihak. dewasa ini kecenderungan semakin memperlihatkan bahwa banyak perjanjian-perjanjian di dalam transaksi bisnis yang terjadi bukan melalui proses negosiasi yang seimbang di antara para pihak. perjanjian itu terjadi dengan cara pihak yang satu telah menyiapkan syarat-syarat baku pada suatu formulir kontrak yang sudah dicetak dan kemudian disodorkan kepada pihak lainnya untuk disetujui dengan hampir tidak memberikan kebebasan sama sekali kepada pihak lainnya untuk melakukan negosiasi atas syarat-syarat yang disodorkan. perjanjian yang demikian itu dinamakan kontrak standar atau kontrak baku atau kontrak adhesi. (Sutan Remy Sjahdeini, 1993: 66)

Kontrak baku, kehadirannya dipenuhi kontroversi yang tidak pernah henti, banyak pakar yang menentang kehadirannya dalam khasanah hukum bisnis, akan tetapi yang mendukung pun tidak sedikit. Fakta yang ada menunjukkan meskipun diliputi kondisi yang kontroversial tersebut. Secara kasat mata kita dapat melihat hampir merata di dalam kehidupan kita, kontrak baku ini selalu muncul dalam berbagai macam kontrak yang dibuat para pihak. (Purwahid Patrik, Makalah, 1995)

Kontroversi yang dibawa oleh kontrak yang berbentuk kontrak baku ini terkait dengan dilanggarnya suatu asas yang sangat dijunjung tinggi dalam dunia kontrak, yaitu Asas Kebebasan Berkontrak (partij autonomie, freedom of contract). Asas ini yang menjadi sumber berkembang pesatnya hukum kontrak, tidak hanya di Indonesia, begitu juga di tingkat regional maupun internasional. (Ery Agus Priyono, Diponegoro Private Law Review, 1, November 2017: 14)

Untuk menghindarkan terjadinya pembuatan perjanjian yang berat sebelah oleh pihak bank, sebagaimana diketahui perjanjian baku dalam industri perbankan hanya dibuat sepihak oleh bank. Oleh karena dibuat 
sepihak oleh bank, maka perjanjian baku itu sering berat sebelah, yaitu hanya memuat hak-hak bank dam kewajiban-kewajiban bank, dan kurang memuat hak-hak dan kewajiban-kewajiban nasabah. Dalam perjanjianperjanjian baku yang disiapkan oleh bank itu, sering dibuat klausulklausul yang sangat menekan nasabah, yang demikian itu adalah bertentangan dengan asas kepatutan atau asas keadilan. Termasuk klausul-klausul yang berat sebelah itu adalah klausul-klausul eksemsi (exemption clauses). Perjanjian-perjanjian yang berat sebelah yang bernada mau menang sendiri di pihak bank itu, pada masa lalu banyak yang dinyatakan oleh pengadilan sebagai perjanjian yang telah dibuat bertentangan dengan asas kepatutan. Sesuai dengan asas hukum perjanjian, maka klausul-klausul yang berat sebelah dan dinilai bertentangan dengan asas kepatutan itu akhirnya dinyatakan sebagai klasul-klausul yang tidak sah dan batal demi hukum.

Hubungan antara bank sebagai pemberi jasa keuangan dan nasabahnya juga harus berlandasakan aspek keadilan, kepatutan, dan keterbukaan (segala sesuatunya harus diperjanjikan diawal sebelum akad ditandatangani oleh para pihak). Berkenaan dengan keadilan dan kepatutan, dalam hubungan tersebut berlaku asas keseimbangan, yaitu akad muamalah harus memperhatikan perlindungan yang seimbang terhadap kepentingan kedua belah pihak, baik pihak bank maupun pihak nasabah. Tidak dibenarkan Akad Muamalah hanya menentukan hak-hak salah satu pihak, biasanya hak-hak bank sebagai pihak yang mengambil posisi yang lebih kuat dari pada nasabah yang memerlukan fasilitas pembiayaan dari bank, dan biasanya pula akad muamalah berbentuk perjanjian (akad) baku. (standart contract atau standardized contract) yang dibuat dan dipersiapkan oleh bank, dan kewajiban-kewajiban pihak lainya biasanya adalah nasabah yang posisi tawarnya lemah menghadapi bank. Akad muamalah harus seimbang menentukan apa yang menjadi hak dan kewajiban masing-masing pihak. (Sutan Remy Sjahdeini, 2014: 134-135) Berdasarkan paparan di atas maka penyeragaman perjanjianperjanjian baku berdasarkan prinsip syariah menjadi sangat penting di dalam sebuah kontrak baik pada tahap pra kontrak maupun tahap pelaksanaan kontrak.

\section{METODE PENELITIAN}

Metode penelitian yang digunakan dalam penulisan ini ini adalah metode penelitian yuridis normatif yang bersifat kualitatif. Metode yuridis normatif yang digunakan dalam penelitian ini adalah untuk menganalisis data yang mengacu kepada norma-norma yang terdapat dalam peraturan perundang- undangan. Metode yuridis normatif ini mengacu pula kepada penelitian yang mengarah kepada dasar filosofis 
perjanjian, khususnya berkaitan dengan landasan filosofis keberadaan prinsip-prinsip syariah.

\section{PEMBAHASAN}

Perjanjian standar (baku) sebenarnya telah dikenal pada zaman romawi kuno. Plato (423- 347 SM), misalnya pernah memaparkan praktik penjualan makanan yang harganya ditentukan secara sepihak oleh si penjual tanpa meperhatikan perbedaan mutu makanan tersebut ( Imelda Matineli, 1977 : 11). Dalam kepustakaan asing dijumpai beberapa istilah. Dalam bahasa Belanda dikenal itilah "Standaard contract", "standaard voorwaarden". Kepustakaaan Jerman digunakan istilah "allgemeine geschalfts bedigung", "standaard konditionen". Hukum Inggris menyebut dengan istilah "Standardized contract', "standard form of contract'( Mariam Darus Badrulzaman, 1980 : 95). Dalam kepustakaan hukum di Indonesia pun demikian. Seperti kerap dijumpai istilah "kontrak standar", "kontrak baku', "perjanjian standar", " perjanjian baku".

Banyak definisi diberikan oleh para pakar hukum tentang definisi Perjanjian Baku tersebut antara lain, Hondius dalam disertasinya mengatakan bahwa: "Perjanjian Baku adalah konsep janji-janji tertulis, disusun tanpa membicarakan isinya dan lazimnya dituangkan ke dalam sejumlah tak terbatas perjanjian yang sifatnya tertentu", sedangkan Mariam Darus, menyimpulkan Perjanjian Baku adalah perjanjian yang isinya dibakukan dan dituangkan dalam bentuk formulir". (Pohan Portomuan, 1994: 2) Tujuan pembuatan perjanjian baku, apa awalnya ini tidak berbeda dengan perjanjian tertulis lainnya, yaitu memberikan manfaat yang seimbang atau proporsional bagi para pihak. Stephen Simister dan Rodney Turner menyatakan dalam karya tulisnya:

... Standard forms of contract purport to provide a representative viewpoint of the industry which they serve. Rather than favour one particular party to the contract, standard forms should represent both parties on an equal and fair basis by providing for an equitable distribution of risk. (Stephen Simister dan Rodney Turner, 2003: 19)

Perjanjian baku adalah perjanjian yang brbentuk tertulis berupa formulir, yang isinya telah di standarisasi atau dibakukan terlebih dahulu secara sepihak oleh kreditor serta bersifat masal tanpa mempertimbangkan perbedaan kondisi yang dimiliki debitur yang dibakukan meliputi model, rumusan, dan ukuran. (Ery Agus Priyono, Diponegoro Private Law Review, 1, November 2017: 16) Pada praktikknya, hampir semua perjanjian khuusnya di dalam dunia bisnis yang berskala besar dan atau berulang, berkelanjutan, perjanjian dilaksanakan dalam bentuk perjanjian baku (standard contract) yang sifatnya membatasi Asas Kebebasan Berkontrak. Latar belakang tumbuhnya perjanjian baku karena keadaan sosial ekonomi, dalam penggunaan perjanjian baku ini, maka 
pengusaha khususnya pemberi waralaba memperoleh efisiensi dalam pengeluaran biaya, tenaga dan waktu. (Ahmad Busro, 2016: 1)

Peraturan dasar dalam hukum Islami adalah factor yang harus dipertimbangkan dalam muamalah atau kontrak (akad) social dan perekonomian adalah perumusan kata-kata yang jelas, bentuk apapun, atau penulisan kontrak (akad). Dengan demikian, barulah kontrak (akad) tersebut memiliki konsekuensi legal, pihak manapun yang memasuki kontrak (akad) tidak dapat mengatakan bahwa keputusanya bukanlah atas niatnya sendiri (niyyah). Hukum akan melaksanakan apa yang telah disetujui oleh pihak lain. Dalam tindakan keagamaan (ibadah), dilain pihak, niat, maksud, atau niyyah dari orang yang bersangkutanlah yang berarti dan bukan kata-kata belaka. Keabsahan kontrak (akad) menuntut bahwa tujuan yang mendasari dan memotivasinya seharusnya sesuai dengan tuntutan syariah. (Muhammad ayub, 2007: 164)

Mengingat perbankan syariah adalah berdasarkan prinsip syariah, maka perjanjian baku (akad) dalam hal muamalah tidak boleh bertentangan dengan prinsip syariah. Apabila terdapat syarat dan ketentuan dalam akad muamalah yang bertentangan dengan prinsip syariah, maka akad tersebut memberikan konsekuensi batal demi hukum. Bank syariah harus mendasarkan sikap Akhlaqul Karimah dalam hubunganya dengan nasabah atau ataupun sebaliknya nasabah kepada banknya. Artinya, antara bank dan nasabah harus didasarkan kepada Akhlak yang didasarkan pada budi pekerti yang luhur. Sesuai dengan sifat hubungan hukum antara bank dan nasabah yang harus berdasarkan Akhlaqul Karimah, perjanjian / akad antara bank dan nasabah juga harus dilaksanakan dengan Iktikad Baik (good faith). (Sutan Remy Sjahdeini, 2014: 137). Hal tersebut sesuai dengan ketentuan Alquran sebagai berikut :

"Dan janganlah sebagian kamu menggunakan harta sebagian yang lain diantara kamu dengan jalan bathil dan (janganlah) kamu membawa (urusan) harta itu kepada hakim, supaya kamu dapat memakan sebagian dari pada harta benda orang lain Itu dengan (jalan berbuat) dosa padahal kamu mengetahu' $i$. (Qs. Al-Baqarah, \{2\}: 188)

Selain ketentuan alquran tersebut, hadist-hadist rasulullah juga mengaharuskan orang selalu berusaha menjadi orang benar dan jujur, tidak curang, sebagaimana berikut:

"Hendaknya kalian selalu berusaha menjadi orang yang benar dan jujur, karena kejujuran akan melahirkan kebaikan-kebaikan (keuntungankeuntungan). Dan kebaikan kan menunjukkan jalan ke surga. Jika seseorang terus berusaha menjadi orang jujur, maka pasti dicatat oleh Allah sebagai orang yang selalu jujur. Jauhilah dusta dan menipu, karena dusta itu akan melahirkan kejahatan dan kejahatan akan menunjukkan jalan ke neraka. Jika seseorang terus-menerus berdusta, maka akan dicatat oleh Allah sebagai orang selalu berdusta." (HR. Bukhari) 
Elemen-elemen dari suatu kontrak (akad), menurut Ayub, mencakup beberapa hal, diantaranya ; Eksistensi kedua belah pihak yang kapabel untuk memasuki kontrak (akad), yakni merek harus dewasa dan waras; Suatu penawaran (ijab) dan penerimaan (qabul); Suatu dasar legal (Sari) mengenai penyatuan dua pernyataan dan kewajiban dari kontrak (akad); Dan terbebas dari semua faktor yang dilarang. Para fuqaha secara umum pada dasarnya memegang teguh bahwa elemen-elemen yang penting dalam kontrak (akad) terdiri dari tiga bagian dan jika elemenelemen ini tidak ada, kontrak (akad)-nya dianggap tidak sah: Format, yakni penawaran dan penerimaan (sighah), Pihak-pihak yang terlibat dalam kontrak (akad) ('aqidain), Subjek (ma'qud 'alayh). (Muhammad ayub, 2007: 165)

Penawaran dan penerimaan dapat disampaikan dalam beragam cara, yaitu: melalui kata-kata, isyarat, indikasi atau tingkah laku. Tidak ada perbedaan pendapat diantara para ahli hukum berkenaan dengan kesimpulan mengenai kontrak-kontrak (akad) melalui kata-kata. Mereka belum menetapkan kata-kata yang pasti dalam pembentukan kontrak tertentu. Apapun yang dapat menyampaikan pengertianya dengan jelas dianggap memadai untuk pembentukan kontrak, meskipun kata-katanya bersifat eksplisit atau implisit tidak akan berbeda.

Para Fuqaha Memiliki Pandangan Bahwa Kontrak (Akad) Harus Dilengkapi oleh penawaran dan penerimaan dalam pertemuan yang sama hingga salah satu pihak mendapatkan hak untuk memikirkan kembali, mengesahkan atau membatalkan kontraknya. (Mansoori, 2005: 30) Sebuah penawaran dianggap batal dalam kasus-kasus berikut: Penarikan kembali penawaran oleh pihak pembuat; Kematian darim suatu pihak atau kehilangan kapasitas untuk memasuki sebuah kontrak (akad); Penghentian majlis, yakni sesi kontraktual, tanpa menyimpulkan kontrak (akad); Perusakan permasalahan.

Dalam rangka mewujudkan sebuah peraturan yang mencerminkan nilai-nilai Pancasila khususnya di dunia bisnis diperlukan penyeragaman perjanjian-perjanjian baku, banyak permasalahan yang dihadapi baik bank maupun nasabah sebagai mitra di dunia bisnis, baik di dalam permasalahan sosial maupun hukum. Diperlukan penyeragaman perjanjian-perjanjian baku dalam implementasinya, dibutuhkan standardisasi yang dapat mewujudkan koordinasi, sinkronisasi, dan harmonisasi kegiatan, sehingga pelaksanaan kegiatan satandardisasi perjanjian-perjanjian baku di Indonesia. Khususnya di dunia perbankan dapat dilakukan secara efisien, efektif, terpadu, terorganisasikan dengan baik dan pada akhirnya dapat meningkatkan efisiensi nasional dan daya saing produk nasional serta perekonomian nasional. Dalam UndangUndang Republik Indonesia Nomor 20 Tahun 2014 Tentang Standardisasi dan Penilaian Kesesuaian, 
Standardisasi dan Penilaian Kesesuaian memiliki tujuan sebagai berikut:

a. Meningkatkan jaminan mutu, efisiensi produksi, daya saing nasional, persaingan usaha yang sehat dan transparan dalam perdagangan, kepastian usaha, dan kemampuan Pelaku Usaha, serta kemampuan inovasi teknologi;

b. Meningkatkan perlindungan kepada konsumen, Pelaku Usaha, tenaga kerja, dan masyarakat lainnya, serta negara, baik dari aspek keselamatan, keamanan, kesehatan, maupun pelestarian fungsi lingkungan hidup; dan

c. Meningkatkan kepastian, kelancaran, dan efisiensi transaksi perdagangan Barang dan/atau Jasa di dalam negeri dan luar negeri.

Pertanyaan yang sering muncul, mengapa perjanjian semacam ini terus saja berkembang dan diterima masyarakat? dari pendapat yang ada ternyata terdapat tiga latar belakang yang mendorong berkembangnya perjanjian baku.

1. Alasan teknis, seperti pendapat yang mengatakan bahwa perbuatanperbuatan hukum sejenis yang selalu terjadi secara berulang-ulang dan teratur yang melibatkan banyak orang menimbulkan keutuhan untuk mempersiapkan isi perjanjian itu terlebih dahulu dan kemudian dibakukan dan seterusnya dicetak dalam jumlah banyak sehingga mudah menyediakan setiap saat jika masyarakat membutuhkan.

2. Latar belakang sosial ekonomi juga turut mendorong lahirnya perjanjian standar (baku) ini, seperti yang dikemukakan oleh Pitlo bahwa latar belakang timbulnya perjanjian baku adalah keadaan sosial ekonomi, perusaah besar, perusahaan pemerintah mengadakan kerjasama dalam suatu organisasi dan untuk kepentingan mereka menentukan syarat-syarat tertentu secara sepihak. Pihak lawannya yang pada umumnya mempunyai kedudukan ekonomi lemah, baik posisinya maupun karena ketidaktahuannya hanya menerima apa yang disodorkannya.

3. Latar belakang yuridis, bahwa keberadaan perjanjian baku merupakan upaya untuk memanfaatkan adanya asas kebebasan berkontrak dari salah satu pihak dalam suatu perjanjian. Seperti diketahui bahwa Pasal 1338 ayat (1) Kitab Undang-Undang Hukum Perdata yang menentukan : "semua perjanjian dibuat secara sah berlaku sebagai Undang- Undang bagi mereka yang membuatnya'. Danty Listiawaty ( Privat Law, 7, 2015: 131)

Ketentuan-ketentuan syariah tersebut mengisyaratkan bahwa perjanjian baik pada waktu pembuatanya maupun pada waktu dilaksanakan harus didasarkan iktikad baik. Asas yang berlaku dalam prinsip syariah tersebut adalah sejalan dengan asas dalam hukum perjanjian sebagaimana diatur dalam KUH Perdata, yaitu dalam pasal 
1338 ayat (3) KUH Perdata, yang menentukan bahwa suatu perjanjian harus dilaksanakan dengan iktikad baik. Ketentuan pasal 1320 (yang menentukan bahwa perjanjian hanya sah apabila dibuat berdasarkan kesepakatan para pihak) dan pasal $1321 \mathrm{KUH}$ Perdata (yang menentukan bahwa kesepakatan tidak boleh diperoleh karena penipuan) mengisyaratkan bahwa perjanjian bukan saja harus dilaksanakan dengan iktikad baik sebagaimana dimaksud oleh pasal 1338 ayat (3) KUH Perdata, tetapi menentukan bahwa perjanjian juga harus dibuat dengan iktikad baik. (Sutan Remy Sjahdeini, 2014: 139).

Suatu akad muamalah atau akad produk bank syariah, hanya dianggap sah apabila memenuhi ketentuan pasal 24 ayat (1) huruf a, pasal 24 ayat (2) dan pasal 25 huruf a serta pasal 26 ayat (1) Undang-undang Nomor 21 Tahun 2008 tentang perbankan syariah. Menurut pasal-pasal tersebut bank syariah dilarang melakukan kegiatan usaha yang bertentangan dengan prinsip syariah. Dengan demikian, berdasarkan Undang-undang Nomor 21 Tahun 2008 tentang perbankan syariah tersebut, maka prinsip syariah diakui memiliki kekuatan hukum sebagai Undang-undang sepanjang menyangkut kegiatan usaha bank syariah. Sesuai dengan asas hukum pada umumnya dan asas hukum perjanjian pada khususnya, prinsip syariah bagi suatu akad produk perbankan syariah merupakan ketentuan khusus terhadap hukum perikatan sebagaimana diatur dalam KUH Perdata, sesuai dengan asas lex specialis derogate legi generalis, bila terdapat perbedaan antara prinsip syariah dan hukum perikatan berdasarkan KUH Perdata, maka yang diberlakukan adalah prinsip syariah sepanjang prinsip syariah itu telah difatwakan oleh Dewan Syariah Nasional-Majelis Ulama Indonesia. (DSN-MU). (Sutan Rfemy Sjahdeini, 2014: 144)

Dengan penyeragaman perjanjian-perjanjian baku perbankan syariah itu, akan dapat dicapai hal-hal sebagai berikut:

1. Lingkup dan isi perjanjian transaksi syariah antara bank syariah yang satu dan bank syariah yang lain tidak menjadi berbeda-beda seperti sekarang ini. Dalam praktik perbankan (terutama praktik perbankan konvensional), antara perjanjian baku yang dibuat dan digunakan oleh satu bank dan bank yang lain sangat berbeda-beda. Ada yang sangat terperinci dan ada yang sangat berbeda.

2. Penyeragaman perjanjian baku perbankan syariah, misalnya, bagi transaksi mudharabah dalam hal penerimaan deposito berjangka,transaksi wadi'ah dalam hal pembukaan rekening giro, transaksi musyarakah, salam, atau murabahah dalam rangka pemberian fasilitas pembiayaan oleh bank syariah, ketentuanketentuan dan syarat-syarat dari perjanjian itu dapat dibuat jelas dan terperinci. Hal itu diperlukan agar isi yang perinci dari perjanjian itu dapat dijadikan acuan apabila terjadi perbedaan pendapat para 
nasabah dan bank. Bukan saja dapat dijadikan acuan oleh para nasabah bank yang pada umumnya tidak menguasai ketentuanketentuan syariah mengenai transaksi-transaksi syariah itu atau oleh penasihat hukumnya, tetapi juga dapat dijadikan acuan oleh hakim yang akan menangani perkara itu apabila sengketa itu sampai harus diselesaikan melalui pengadilan agama atau badan arbitrase syariah nasional atau arbiter.

3. Pengadilan juga berpendirian bahwa dalam hal kemudian bank menjalankan haknya, melakukan tindakan terhadap nasabah berdasarkan klausul-klausul yang berat sebelah itu, pengadilan akan menganggap bank telah melakukan perbuatan melawan hukum. Tindakan bank tersebut terancam dinyatakan tidak sah dan dibatalkan oleh pengadilan. Dalam banyak kasus, pengadilan sering pula berpendirian bahwa dalam hal pembuatan perjanjian yang berat sebelah itu, bank dianggap telah melakukan "penyalahgunaan keadaan" atau "misbruik van omstan digheden" artinya, pada waktu perjanjian itu dibuat, pengadilan berpendapat bahwa bank telah menyalahgunakan keadaan nasabah yang lemah dan tidak berdaya dalam menghadapi bank yang bargaining power-nya lebih kuat, sementara itu nasabah sangat membutuhkan fasilitas pembiayaan yang dimaksud dan apabila nasabah menolak klausul-klausul yang meberatkan itu, maka bank akan menolak untuk memberikan fasilitas pembiayaan yang sangat dibutuhkan oleh nasabah itu, sehingga nasabah terpaksa menerima saja kemauan bank yang memberatkan nasabah itu. Bila pengadilan menganggap bahwa bank telah melakukan "penyalahgunaan keadaan", maka berarti perjanjian itu telah dibuat berdasarkan kesepakatan murni antara bank dan nasabah yang merupakan unsur yang menentukan bagi sahnya pembuatan perjanjian itu. Sebagai akibat dari dinilainya perjanjian itu sebagai telah dibuat berdasarkan "penyalahgunaan keadaan", maka seluruh perjanjian itu telah dinyatakan batal demi hukum oleh pengadilan. (Sutan Remy Sjahdeini, 2014: 145)

Semua transaksi, agar menjadi sah dan dapat dilaksanakan, harus didasarkan pada persetujuan bersama yang bebas dari paksaan oleh kedua belah pihak. Persetujuan yang dibutuhkan untuk pembentukan suatu kontrak (akad) yang sah adalah persetujuan yang bebas. Persetujuan yang diperoleh melalui penekanan, penipuan, dan persepsi yang salah membuat suatu kontrak (akad) tidak sah sesuai dengan hukum islami. Ia juga menuntut pihak-pihak yang menyetujuinya memiliki pengetahuan tertentu dan jelas mengenai subjek kontrak (akad) serta hak dan kewajiban yang muncul darinya. Oleh sebab itu, pemeriksaan atas subjek dan dokumentasi yang memadai dari transaksi, khususnya apabila melibatkan kredit, mendapatkan dukungan dan 
penekanan. Praktik-praktik seperti Najas (tawaran harga yang palsu), Ghaban-Alfahis (mengenakan harga yang terlalu tinggi sambal memberikan kesan bahwa yang dikenakan adalah harga pasar), dan penyembunyian cacat material apapun pada barang atau informasi mengenai nilai dalam penjualan kepercayaan seperti murabahah dilarang dengan tegas sehingga semua pihak dapat memutuskan dengan kemauan bebas dan keyakinan. (Muhammad Ayub, 2007: 172)

\section{KESIMPULAN}

Perjanjian baku pada dasarnya tidak dilarang ketika mengingat kebutuhan praktik yang menuntut dibuatnya perjanjian yang mempertimbangan aspek efisiensi, baik dari segi waktu, biaya, dan tenaga. Sesuai dengan asas hukum perjanjian, maka klausul-klausul yang berat sebelah dan dinilai bertentangan dengan asas kepatutan itu akhirnya dinyatakan sebagai klasul-klausul yang tidak sah dan batal demi hukum. Penting dan sangat diperlukan penyeragaman perjanjianperjanjian baku untuk memberikan kesimbangan antara bank syariah dan para nasabahnya oleh bank Indonesia. Karena pada saat ini di Indonesia belum memilili landasan legal berupa Undang-undang tentang Perjanjian Baku, sebagaimana Undang-undang semacam itu telah dipunyai oleh banyak di negara maju. Sehubungan dengan hubungan hukum antara bank syariah dan nasabahnya akan dipertanyakan ketika melanggar prinsip-prinsip syariah, dibutuhkan ketegasan bank Indonesia dengan bantuan dewan syariah nasional dapat melakukan penyeragaman terhadap perjanjian-perjanjian baku (standart contract) yang dapat digunakan oleh bank-bank syariah di Indonesia.

\section{DAFTAR PUSTAKA}

Ayub, Muhammad 2007, Undersatnding Islamic Finance

Badrulzaman, Mariam Darus , 2001, Kompilasi Hukum Perikatan, Bandung, Citra Adtya Bakti.

Busro, Ahmad, 2016.Pengaruh Perjanjian Baku Terhadap Penerapan Asas Kebebasan Berkontrak Dalam Rangka Menyongsong Masyarakat Ekonomi Asean, Naskah Pidato Pengukuhan Guru Besar Fh Undip.

Imelda Martenelli."Tiga Lsu Penting Dalam Transaksi Konsumen'”. Era Hukum, No. 11/ Thn 3/1997 Jakarta: Fakultas Hukum, Universitas Tarumanegara.

Patrik, Purwahid 1995, Perjanjian Baku Dan Syarat-Syarat Eksonerasi, Makalah Penataran Dosen Perdata, Semarang.

Portomuan, Pohan 1994, Penggunaan Kontrak Baku Dalam Praktek Bisnis Di Indonesia. Majalah Bphn. Jakarta. 
Priyono, Ery Agus, 2017. Peranan Asas Itikad Baik Dalam Kontrak Baku (Upaya Menjaga Keseimbangan Bagi Para Pihak) Diponegoro Private Law Review Vol. 1: 16

(Qs. Al-Baqarah, \{2\}: 188)

Simister, Stephen Dan Rodney Turner 2003, Standard Form Of Contracts, Hamshire, Gower Publishing Limited.

Sjahdeini, Sutan Remy 2014, Perbankan Syariah, Produk-Produk Dan Aspek Hukumnya, Penerbit Prenada Kencana.

Triyanta, Agus 2016, Hukum Perbankan Syariah, Setara Press 
Moh Abdul Latif

Halaman ini sengaja dikosongkan 